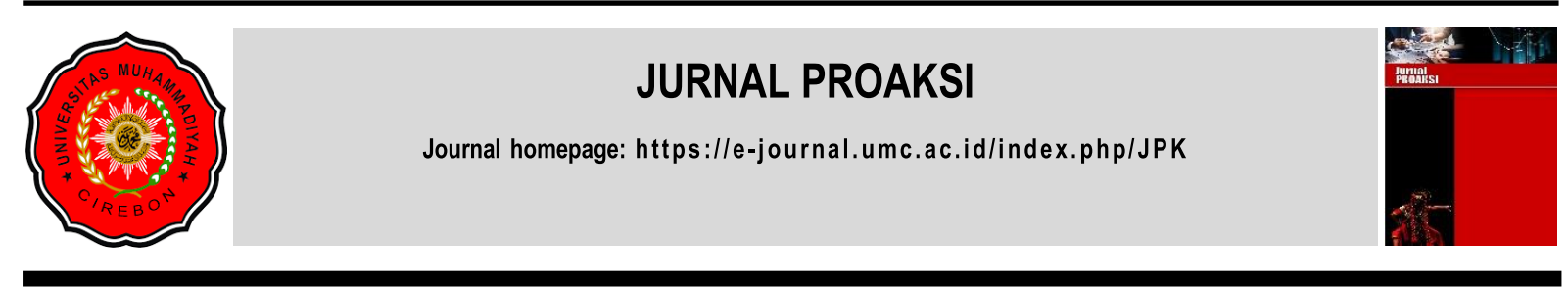

\title{
ANALISIS PROFITABILITAS DAN LEVERAGE TERHADAP RETURN SAHAM PADA SEKTOR PERTAMBANGAN BATU BARA
}

\author{
Larasati Kusuma Wardani ${ }^{1}$, \\ Gideon Setyo Budiwitjaksono ${ }^{2 *}$ \\ ${ }^{1}$ Fakultas Ekonomi dan Bisnis, Universitas Pembangunan Nasional "Veteran" Jawa Timur \\ Email:17013010111@student.upnjatim.ac.id \\ ${ }^{2}$ Fakultas Ekonomi dan Bisnis, Universitas Pembangunan Nasional "Veteran" Jawa Timur \\ *Corresponding Author : Email : gideon.ak@upnjatim.ac.id
}

Diterima : 25 April 2021

Direvisi : 7 Mei 2021

Dipublikasikan : 19 Juli 2021

\begin{abstract}
The current condition of the capital market is full of uncertainty, which can be seen from fluctuations in stock prices and Returns. The volatility of the company's stock price can indicate that investors have not obtained optimal stock Returns. This study aims to examine the effect of profitability and Leverage on stock Returns in the coal mining sector listed on the IDX in 2017-2019. This research uses associative research with a quantitative approach. The population used is all coal mining sectors listed on the IDX in 2017-2019 and the sample is used for purposive sampling that is 16 companies. Secondary data is used by accessing the official IDX website then downloading the annual financial reports of the coal mining sector for 2017-2019. Multiple linear regression was used as analysis in this study with statistical software. The results of the study state that profitability and Leverage have no effect on stock Returns in the coal mining sector which is listed on the Indonesia Stock Exchange in 20172019.
\end{abstract}

Keywords: Leverage, Profitabilitas, Return Saham

\section{PENDAHULUAN}

Suatu perusahaan membutuhkan pasar modal sebagai sarana yang berperan penting sebagai upaya untuk mendapat dana dari pemilik modal. Dana yang didapatkan dari pasar modal dibutuhkan dalam meningkatkan usaha dan modal perusahaan. Di Indonesia, Bursa Efek Indonesia menjadi alternatif perusahaan. Untuk memperoleh dana tersebut maka perusahaan perlu meningkatkan performa usahanya sehingga investor akan tertarik untuk berinvestasi. Semakin baik dan tingginya kualitas serta performa perusahaan, harga saham akan meningkatkan sehingga terjadi peningkatan Return saham. Profit yang diterima pemilik modal atas investasi yang ditanamkan disebut Return saham (Jogiyanto, 2013). Return saham menjadi motivasi para investor dalam berinvestasi walaupun ketidakstabilan Return yang tinggi akan berakibat tingginya risiko yang akan diterima investor. Oleh karena itu, sebelum melakukan investasi maka investor perlu menganalisis mengenai pergerakan saham yang berubah-ubah (Aisah \& Mandala, 2016; Almira \& Wiagustini, 2020).

Pertambangan di Indonesia memberikan nilai jual produk yang sangat bernilai. Saat ini banyak perusahaan dunia yang mulai mengalihkan fokus energi ke batu bara. Indonesia merupakan salah satu penghasil batu bara terbesar dunia yang menjadi pusat serta pilar utama ekspansi ekonomi Indonesia. Industri batu bara berperan besar dalam pembangunan nasional di berbagai sektor ekonomi dengan memberikan kontribusi terhadap penerimaan negara yang berasal dari pembayaran pajak termasuk royalti. Perkembangan batu bara terus menjadi sumber energi vital yang diperlukan di masa depan sehingga penelitian ini berfokus pada sektor pertambangan batu bara. 
Kondisi pasar modal saat ini penuh dengan ketidakpastian yang terlihat dari fluktuasi harga saham maupun Return. Berikut adalah ringkasan kenaikan harga saham sektor pertambangan Indonesia. Berdasarkan Bursa Efek Indonesia, Pada tahun 2017 hingga 2018 terjadi kenaikan harga saham akan tetapi pada tahun 2019, terjadi penurunan harga saham hingga negatif $12,83 \%$. Terkait dengan fenomena volatilitas harga saham perusahaan dapat mengindikasikan bahwa investor belum memperoleh Return saham secara optimal. Sehingga, sangat penting bagi perusahaan meningkatkan kinerja perusahaan agar terjadi peningkatan terhadap harga saham perusahaan. Return saham adalah motivasi investor untuk berinvestasi (Sari \& Priyadi, 2016). Teori sinyal digunakan untuk memberikan sinyal positif maupun negatif kepada investor mengenai kualitas perusahaan sehingga investor dapat mengetahui di masa depan perusahaan akan memiliki penghasilan yang baik atau tidak. Sinyal positif perusahaan diperlukan karena harga saham dan Return yang dihasilkan akan semakin meningkat ketika banyak investor yang berinvestasi (Fenty, 2017). Terdapat banyak faktor yang dapat memengaruhi Return saham diantaranya yaitu, rasio profitabilitas dan Leverage. Terjadinya penurunan harga saham pada tahun 2019 diduga dipengaruhi oleh rasio profitabilitas dan Leverage yang mencerminkan kinerja keuangan perusahaan karena rasio tersebut menunjukkan sumber daya perusahaan secara optimal mampu dalam menghasilkan laba.

Sebelum berinvestasi, investor menggunakan profitabilitas sebagai ukuran dalam menentukan keberhasilan perusahaan serta kinerja perusahaan (Kasmir, 2015). Rasio profitabilitas memiliki berbagai jenis yang dapat mempengaruhi Return saham yaitu Gross Profit Margin (GPM), Operating Profit Margin (OPM), Net Profit Margin (NPM), Return On Asset (ROA), Return On Equity(ROE), Return On Sales (ROS), Return On Capital Employed (ROCE), Return On Investment (ROI), dan Earning Per Share (EPS). Pada pengkajian ini, profitabilitas memakai ROE sebagai pengukur mampu atau tidaknya suatu perusahaan dalam menghasilkan keuntungan terhadap ekuitas atau modal yang diberikan oleh pemegang saham (Almira \& Wiagustini, 2020). ROE digunakan karena ROE sangat penting bagi pemegang saham untuk mengetahui pengelolaan modal yang diterapkan perusahaan serta menunjukkan kemampuan dalam menghasilkan laba dengan menggunakan modal yang dimiliki perusahaan (Mahardika \& Artini, 2017). ROE menjadi tolok ukur perusahaan dalam memperoleh keuntungan dan investor dapat menilai pertumbuhan profitabilitas serta kinerja perusahaan. Semakin tinggi profitabilitas maka semakin baik pula kinerja perusahaan. Return yang diterima investor akan lebih tinggi apabila perusahaan memiliki ROE yang tinggi sehingga para pemegang saham akan semakin percaya pada perusahaan. Penelitian dari Fitriana et al. (2016), Kevin et al. (2020), dan Saputra \& Dharmadiaksa (2016) menunjukkan peningkatan profitabilitas yang diproksikan dengan ROE akan ditunjukkan dengan meningkatnya keuntungan bersih serta peningkatan harga saham dan deviden berupa Return. Namun, penelitian Aisah \& Mandala (2016), Aulidani et al. (2020), Fitri (2018), dan Kampongsina et al. (2020) menyatakan profitabilitas tidak berpengaruh terhadap Return saham.

Leverage merupakan kompetensi perusahaan dalam melunasi seluruh hutang dan berperan penting sebagai pertimbangan investor dalam melakukan investasi. Rasio Leverage memiliki berbagai jenis yang dapat mempengaruhi Return saham, yaitu Debt to Asset Ratio(DAR), Debt to Equity Ratio(DER), Times-Interest-Earned Ratio (TIE), Fixed Charge Coverage Ratio, dan Cash Flow Interest Coverage Ratio. Pada pengkajian ini, Leverage menggunakan DER dalam mengukur kemampuan perusahaan dalam melunasi kewajiban. DER digunakan karena berperan penting bagi investor dalam melakukan pertimbangan penilaian saham dan juga untuk meningkatkan penghasilan bagi pemilik perusahaan (Sari \& Priyadi, 2016). Tingginya tingkat Leverage pada perusahaan sangat rentan mengalami kesulitan keuangan dan terancam bangkrut. Investor dalam berinvestasi, tertarik pada perusahaan yang memiliki DER rendah karena DER yang tinggi dapat memengaruhi risiko pertumbuhan kinerja perusahaan dan harga sahamnya. Pada penelitian Fitriana et al. (2016), Putra \& Dana (2016), dan Sari \& Priyadi (2016) menyatakan Leverage berpengaruh negatif terhadap Return saham karena tingginya risiko pinjaman akan berpengaruh buruk bagi para investor dan menurunnya harga saham serta memengaruhi Return saham. Namun, pada penelitian dari Aisah \& Mandala (2016), Aulidani et al. (2020), dan Fitri (2018) menyatakan Leverage mempengaruhi Return saham. Rasio profitabilitas dan Leverage digunakan sebagai ukuran penelitian karena kedua rasio tersebut telah menjadi perhatian investor sebab mudah dipahami dan dianggap telah menunjukkan kondisi suatu perusahaan (Sari \& Priyadi, 2016). Investor dalam berinvestasi akan menganalisa laporan keuangan perusahaan seperti rasio profitabilitas yang memaparkan informasi hasil akhir seluruh kebijakan keuangan dan keputusan operasional yang dilakukan oleh manajemen suatu perusahaan serta rasio 
Leverage yang menunjukkan hutang perusahaan dan pengaruh tingkat hutang terhadap pendapatan bersih yang akan diperoleh (Martha et al., 2018). Adanya rasio profitabilitas dan Leverage dalam laporan keuangan dapat digunakan investor untuk mengidentifikasi apakah perusahaan memiliki kinerja lebih baik atau lebih buruk dari pesaing industri yang sama (Kasmir, 2015). Berdasarkan uraian tersebut maka penelitian ini dikatakan representative.

Industri di dunia banyak yang mulai mengalihkan fokus energi ke batu bara. Indonesia adalah salah satu produsen batu bara terbesar di dunia dan menjadi pusat dan pilar utama ekspansi ekonomi Indonesia. Sektor pertambangan batu bara di Indonesia berpotensi sangat besar bagi perekonomian domestik dan memberikan efek bagi perekonomian sehingga akan banyak perkembangan unit aktivitas ekonomi. Pada industri sektor batu bara terjadi kenaikan harga yang sebagian besar dipicu oleh pertumbuhan ekonomi negara-negara berkembang sehingga perkembangan batu bara menjadi sumber energi vital yang akan diperlukan di masa depan. Oleh karena itu, maka penelitian ini akan fokus pada sektor pertambangan batu bara.

Atas pandangan penelitian sebelumnya, ditemukan adanya inkonsistensi hasil penelitian, maka perlu diteliti dan dianalisis kembali mengenai Return saham sehingga peneliti tertarik untuk meneliti kembali terkait "Analisis Profitabilitas dan Leverage terhadap Return saham pada sektor pertambangan batu bara".

\section{KAJIAN PUSTAKA DAN PENGEMBANGAN HIPOTESIS}

Teori sinyal menunjukkan laporan keuangan digunakan perusahaan untuk memberikan sinyal yang ditujukan pada investor (Jogiyanto, 2013). Investor dapat mengetahui apakah di masa depan perusahaan akan memiliki penghasilan yang baik atau tidak melalui sinyal yang diberikan perusahaan. Sinyal positif perusahaan diperlukan karena harga saham dan Return yang dihasilkan akan semakin meningkat ketika banyak investor yang (Fenty, 2017).

Profit yang diterima pemilik modal atas investasi yang ditanamkan disebut Return saham(Jogiyanto, 2013). Return umumnya berupa persentase terhadap harga beli, tingginya harga jual saham akan meningkatkan Return yang didapatkan investor (Almira \& Wiagustini, 2020). Tingginya Return yang diberikan kepada investor menunjukkan bahwa baiknya kinerja perusahaan sehingga investor akan melihat bahwa perusahaan bernilai positif terhadap saham yang ditanamkan(Bisara \& Amanah, 2015; Saputra \& Dharmadiaksa, 2016). Investor akan tertarik dalam berinvestasi apabila Return yang dihasilkan tinggi.

Rasio keuangan merupakan informasi penting untuk mengetahui performa perusahaan. Kondisi keuangan dan performa perusahaan dapat diungkapkan pada rasio keuangan dengan membandingkan angka-angka pada laporan keuangan (Kasmir, 2015). Terdapat banyak rasio yang memengaruhi Return saham diantaranya yaitu, profitabilitas dan Leverage yang memperlihatkan kinerja keuangan perusahaan karena rasio tersebut menunjukkan sumber daya perusahaan secara optimal mampu dalam menghasilkan laba.

Profitabilitas merupakan ukuran keberhasilan perusahaan dalam menghasilkan laba. Tingginya nilai laba menunjukkan bahwa suatu perusahaan secara optimal akan menggunakan modal untuk menghasilkan keuntungan yang tinggi (Fitriana et al., 2016). Sebelum berinvestasi, investor sering menggunakan profitabilitas sebagai ukuran dalam menentukan keberhasilan perusahaan serta kinerja perusahaan (Kasmir, 2015). Akan baik bagi perusahaan apabila memiliki rasio profitabilitas yang tinggi. Return On Equity (ROE) adalah keterkaitan antar profitabilitas dengan modal (Prihadi, 2016). ROE mendeskripsikan kompetensi perusahaan untuk menghasilkan profit bagi pemegang saham. Semakin tingginya ROE akan memengaruhi peningkatan harga saham dan laba yang dihasilkan juga semakin tinggi serta akan meningkatkan perolehan Return saham (Almira \& Wiagustini, 2020). ROE sangat menarik bagi investor maupun manajemen karena dengan tingginya ROE maka kualitas kinerja perusahaan akan baik dan Return saham yang diperoleh akan meningkat (Fitri, 2018). ROE menunjukkan tingkat Return saham yang dikelola manajemen dan dapat mengetahui efisiensi pengelola manajemen (Tumiur, 2019). Adanya ROE maka investor dapat menilai pertumbuhan profitabilitas serta kinerja perusahaan(Safitri et al., 2015).

Leverage adalah kemampuan perusahaan dalam memenuhi seluruh hutang (Sayidah, 2019). Leverage berperan penting bagi investor dalam melakukan pertimbangan penilaian saham dan juga untuk meningkatkan penghasilan bagi pemilik perusahaan. Tingginya tingkat Leverage pada perusahaan sangat rentan mengalami kesulitan keuangan dan terancam bangkrut karena berlebihan 
dalam menggunakan hutang dan tidak mampu melunasinya (Sari \& Priyadi, 2016). Debt Equity Ratio (DER) digunakan dalam Leverage untuk membandingkan antar hutang dan aktiva perusahaan sehingga menunjukkan perusahaan mampu melunasi hutang. Nilai DER dapat memengaruhi risiko pertumbuhan kinerja perusahaan dan harga sahamnya (Saputra \& Dharmadiaksa, 2016). Semakin tinggi nilai DER menunjukkan bahwa Return yang diterima akan semakin kecil karena akan meningkatkan risiko investor sehingga perusahaan dapat likuidasi karena tingginya hutang dan Return saham pun akan mengalami penurunan (Bisara \& Amanah, 2015). Berikut adalah model teoritis penelitian ini:

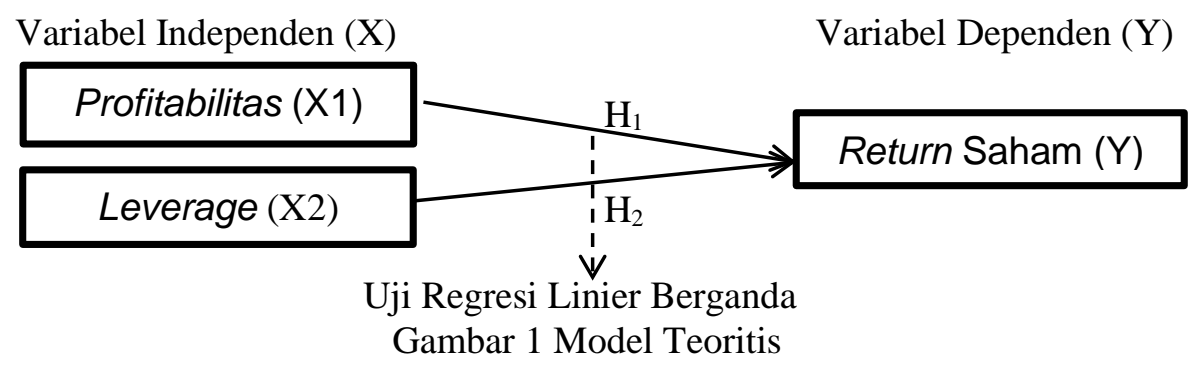

\section{Pengaruh Profitabilitas terhadap Return Saham}

Tingginya nilai laba menunjukkan bahwa suatu perusahaan secara optimal akan menggunakan modal untuk menghasilkan keuntungan yang tinggi sehingga profitabilitas menggunakan ROE untuk mengukur kemampuan perusahaan dalam memperoleh laba (Fitriana et al., 2016). Semakin tinggi ROE maka akan meningkatkan permintaan saham perusahaan yang akan mendorong naiknya harga saham dan Return yang diterima investor akan semakin tinggi (Sari \& Priyadi, 2016). Berdasarkan uraian tersebut, dapat dinyatakan dalam bentuk hipotesis berikut:

\section{$\mathrm{H}_{1}$ : Profitabilitas berpengaruh terhadap Return saham.}

\section{Pengaruh Leverage terhadap Return Saham}

Leverage berperan penting bagi investor dalam melakukan pertimbangan penilaian saham dan juga untuk meningkatkan Return bagi pemilik perusahaan. Tingginya tingkat Leverage pada perusahaan sangat rentan mengalami kesulitan keuangan dan terancam bangkrut karena hutang yang banyak dan tidak mampu melunasinya (Sari \& Priyadi, 2016). Investor cenderung menghindari saham perusahaan yang memiliki DER tinggi karena merupakan cerminan tingginya risiko perusahaan. Nilai DER dapat mempengaruhi risiko pertumbuhan kinerja perusahaan dan harga sahamnya sehingga permintaan saham turun dan harga saham pun mengalami penurunan yang menyebabkan rendahnya Return yang akan diterima investor (Safitri et al., 2015). Berdasarkan uraian tersebut, dapat dinyatakan dalam bentuk hipotesis berikut:

\section{$\mathrm{H}_{2}$ : Leverage berpengaruh terhadap Return saham.}

\section{METODE PENELITIAN}

Penelitian asosiatif dengan pendekatan kuantitatif dipakai untuk mengkaji antar suatu variabel dengan variabel lainnya. Objek pengkajian menggunakan laporan keuangan tahunan sektor pertambangan batu bara yang terdaftar di BEI tahun 2017-2019. Data sekunder digunakan dengan dengan mengakses website resmi BEI. Populasi yang digunakan adalah seluruh sektor pertambangan batu bara yang terdaftar di BEI tahun 2017-2019. Sampel yang dipakai berdasarkan kriteria yang telah ditetapkan (purposive sampling). Berikut adalah ringkasan sampel penelitian:

Tabel 1

Kriteria Sampel Penelitian

\begin{tabular}{llc}
\hline No & \multicolumn{1}{c}{ Kriteria } & Jumlah Sampel \\
\hline 1 & $\begin{array}{l}\text { Perusahaan sektor Pertambangan batu bara yang } \\
\text { terdaftar di BEI tahun 2017-2019 }\end{array}$ & 26 \\
2 & $\begin{array}{l}\text { Perusahaan yang tidak menerbitkan Laporan } \\
\text { Keuangan Tahunan periode 2017-2019 }\end{array}$ & $(0)$ \\
3 & $\begin{array}{l}\text { Perusahaan yang tidak memiliki laba } \\
\text { Jumlah }\end{array}$ & $(10)$ \\
\hline
\end{tabular}

Sumber: data yang diolah 
Menurut tabel 1, data penentuan sampel yang akan dianalisis berjumlah 48 (16 x 3 periode pengamatan). Dokumentasi digunakan pada teknik pengumpulan data. Dokumentasi dilakukan dengan cara mengakses website resmi dan mengunduh laporan keuangan tahunan perusahaan tambang batu bara yang terdaftar di BEI tahun 2017-2019. Regresi linier berganda digunakan sebagai analisis pada pengkajian ini dengan memakai alat statistik berupa SPSS versi 22 untuk mengolah, menganalisis, serta menginterpretasikan data. Metode analisis data yang dipakai, yaitu:

1. Uji Normalitas

Guna memahami variabel residual suatu regresi telah terdistribusi normal maka digunakan uji normalitas.

2. Uji Asumsi Klasik

a. Uji Multikolinieritas

Guna memahami adanya korelasi tinggi pada variabel bebas.

b. Uji Autokorelasi

Guna memahami adanya korelasi antar residual saat ini dengan periode lalu.

c. Uji Heterokedastisitas

Guna memahami adanya kesamaan variasi residual dalam regresi.

3. Regresi Linier Berganda

Guna mengukur pengaruh profitabilitas dan Leverage pada Return saham, maka dipakai regresi linier berganda. Rumus yang dipakai, ialah:

$$
\mathrm{Y}=\alpha+\beta_{1} \mathrm{X}_{1}+\beta_{2} \mathrm{X}_{2}+\varepsilon
$$

$\begin{array}{ll}\text { Keterangan: } \\ \mathrm{Y} & \text { : Return saham } \\ \alpha & : \text { Konstanta } \\ \beta_{1}, \beta_{2} & : \text { Slope } \\ \mathrm{X}_{1} & : \text { ROE } \\ \mathrm{X}_{2} & : \text { DER } \\ \varepsilon & : \text { error }\end{array}$

4. Uji Hipotesis yang dipakai adalah:

a. Uji Kecocokan Model

Guna memahami pengaruh keseluruhan antar variabel bebas terhadap variabel terikat (Ghozali, 2011).

b. Uji t

Untuk memahami sejauh mana variabel bebas dalam menguraikan variabel terikat secara parsial (Ghozali, 2013).

\section{HASIL DAN PEMBAHASAN}

\section{Uji Normalitas}

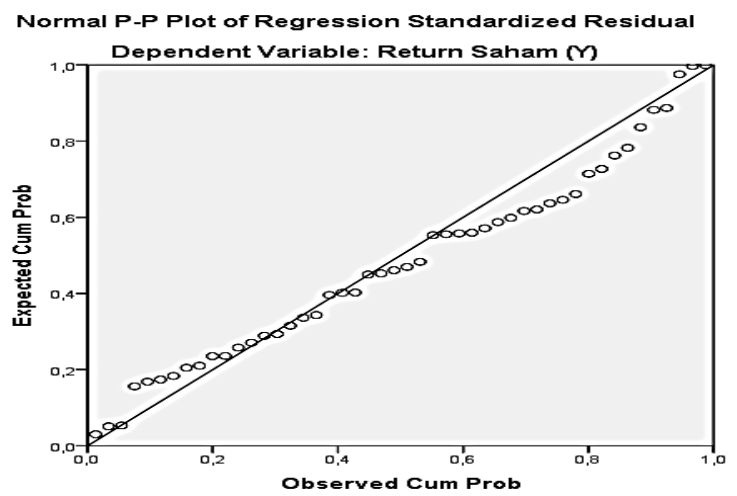

Gambar 1 Hasil Uji Normalitas Metode Grafik

Uji normalitas diperlukan untuk mengetahui bahwa data yang digunakan dalam penelitian telah terdistribusi normal atau tidak. Berdasarkan gambar 1, diketahui bahwa titik-titik mengikuti garis 
diagonal sehingga atas dasar pengambilan keputusan menurut Ghozali (2011), maka model regresi dinyatakan terdistribusi normal sehingga data dapat digunakan dalam penelitian ini.

\section{Uji Asumsi Klasik}

Uji Multikolinieritas

Tabel 2

Hasil Uji Multikolinieritas

\begin{tabular}{|c|c|c|c|c|c|c|c|c|}
\hline \multicolumn{9}{|c|}{ Coefficients $^{a}$} \\
\hline & \multirow[b]{2}{*}{ Model } & \multicolumn{2}{|c|}{$\begin{array}{c}\text { Unstandardized } \\
\text { Coefficients }\end{array}$} & \multirow{2}{*}{$\begin{array}{c}\text { Standardized } \\
\text { Coefficients } \\
\text { Beta }\end{array}$} & \multirow[b]{2}{*}{$t$} & \multirow[b]{2}{*}{ Sig. } & \multicolumn{2}{|l|}{$\begin{array}{l}\text { Collinearity } \\
\text { Statistics }\end{array}$} \\
\hline & & $B$ & $\begin{array}{l}\text { Std. } \\
\text { Error }\end{array}$ & & & & Tolerance & $V I F$ \\
\hline \multirow[t]{3}{*}{1} & (Constant) & $-0,076$ & 0,132 & & $-0,572$ & 0,57 & & \\
\hline & $\operatorname{ROE}(X 1)$ & 0,007 & 0,004 & 0,246 & 1,705 & 0,095 & 1,000 & 1,000 \\
\hline & $D E R(X 2)$ & 0,003 & 0,080 & 0,005 & 0,035 & 0,972 & 1,000 & 1,000 \\
\hline
\end{tabular}

Sumber : data yang diolah

Uji Multikolinieritas digunakan untuk menguji apakah dalam model regresi ditemukan adanya korelasi tinggi pada ROE dan DER. Menurut tabel 2, diketahui nilai toleransi ROE dan DER menghasilkan VIF < 10 dan tolerance $>0,10$, memperlihatkan tidak adanya multikolinieritas. sehingga dapat disimpulkan bahwa tidak terdapat multikolinieritas antar variabel independen.

\section{Uji Autokorelasi}

Tabel 3 Hasil Uji Autokorelasi

\begin{tabular}{lccccc}
\hline \multicolumn{7}{c}{ Model Summary $^{b}$} \\
Model & $R$ & $R$ Square & Square & $\begin{array}{l}\text { Std. Error of } \\
\text { the Estimate }\end{array}$ & $\begin{array}{l}\text { Durbin- } \\
\text { Watson }\end{array}$ \\
\hline 1 & $0,246^{\text {a }}$ & 0,061 & 0,019 & 0,48390 & 2,316 \\
\hline a. Predictors (Constant), DER $(X 2), \operatorname{ROE}(X 1)$ \\
b. Dependent Variable: Return Saham $(Y)$
\end{tabular}

Sumber : data yang diolah

Uji Autokorelasi digunakan untuk menguji adanya korelasi antar residual saat ini dengan periode lalu. Uji autokorelasi penelitian ini menggunakan Durbin-Watson untuk mendeteksi ada atau tidaknya autokorelasi. Menurut tabel 3, diketahui bahwa du (k:2 ; N:48 dengan Sig. 5\%) yaitu 1,6231 sehingga du $(1,6231)$ < Durbin-Watson $(2,316)<4$-du $(2,3769)$ maka dinyatakan tidak ada autokorelasi. Berdasarkan hal tersebut maka dapat disimpulkan bahwa penelitian ini telah lolos uji Durbin-Watson yang menunjukkan bahwa tidak terdapat autokorelasi.

\section{Uji Heterokedastisitas}

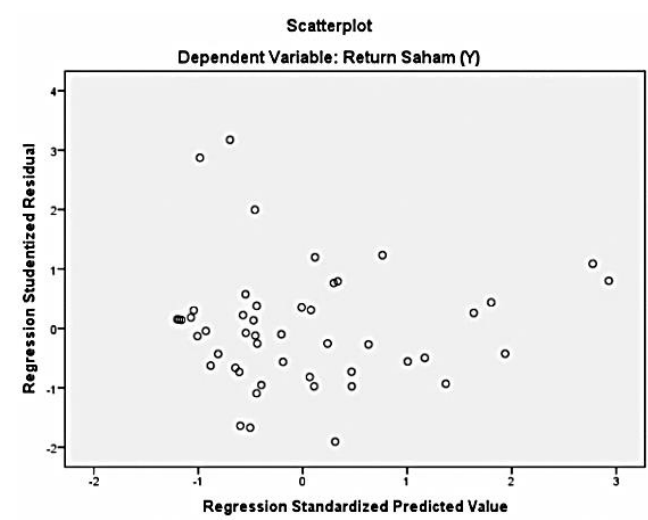

Gambar 2 Hasil Uji Heterokedastisitas dengan Scatterplot

Uji Heterokedastisitas digunakan untuk menguji adanya kesamaan variasi residual dalam regresi. Menurut gambar 2, terdapat ketidakjelasan pola (pola gelombang, melebar kemudian 
menyempit), serta titik-titik menyebar di atas dan di bawah angka 0 pada sumbu Y. Hal tersebut menunjukkan bahwa pada penelitian ini tidak terdapat gejala heterokedastisitas.

\section{Analisis Regresi Linier Berganda}

Analisis regresi linier berganda digunakan untuk menguji pengaruh profitabilitas dan Leverage terhadap Return saham pada sektor pertambangan batu bara yang terdaftar di BEI tahun 2017-2019.

Tabel 4

Ringkasan Hasil Analisis Regresi Linier Berganda

\begin{tabular}{lrlrcrcr}
\hline Variabel & \multirow{2}{*}{ Koefisien } & \multirow{2}{*}{ Konstanta } & \multicolumn{2}{c}{ Nilai R } & $\mathbf{F}$ & $\mathbf{t}$ & \multirow{2}{*}{ Sig. } \\
\cline { 4 - 7 } & & & $\mathbf{R}_{\text {hitung }}$ & $\mathbf{R}^{\mathbf{2}}$ & $\mathbf{F}_{\text {hitung }}$ & $\mathbf{t}_{\text {hitung }}$ & \\
\hline ROE & 0,007 & \multirow{2}{*}{0,076} & 0,246 & 0,061 & 1,453 & 0,095 & 0,245 \\
DER & 0,003 & & & & & 0,972 & \\
\hline
\end{tabular}

Sumber : data yang diolah

Menurut tabel 4, dituliskan persamaan regresi yaitu:

$$
\mathrm{Y}=-0,076+0,007 \mathrm{X}_{1}+0,003 \mathrm{X}_{2}+\varepsilon
$$

Persamaan regresi menyatakan nilai konstanta $-0,076$. Sehingga dapat dinyatakan jika variabel ROE dan DER dianggap konstan maka Return saham 0,076. Koefisien ROE 0,007 menunjukkan jika ROE naik satu ukuran maka Return saham naik 0,007 (DER dianggap konstan). Koefisien DER 0,003 menunjukkan jika DER naik satu ukuran maka Return saham naik 0,003 (ROE dianggap konstan).

\section{Uji Hipotesis}

\section{Uji Kecocokan Model}

Tabel 5

Hasil Uji Kecocokan Model

\begin{tabular}{|c|c|c|c|c|c|c|}
\hline \multicolumn{7}{|c|}{$A N O V A^{a}$} \\
\hline \multicolumn{2}{|l|}{ Model } & $\begin{array}{l}\text { Sum of } \\
\text { Squares }\end{array}$ & $d f$ & $\begin{array}{l}\text { Mean } \\
\text { Square }\end{array}$ & $F$ & Sig. \\
\hline \multirow[t]{3}{*}{1} & Regression & 0,68 & 2 & 0,340 & 1,453 & $0,245^{\mathrm{b}}$ \\
\hline & Residual & 10,537 & 45 & 0,234 & & \\
\hline & Total & 11,218 & 47 & & & \\
\hline
\end{tabular}

a. Dependent Variable: Return Saham (Y)

b. Predictors: (Constant), DER (X2), ROE (X1)

Sumber : data yang diolah

Uji Kecocokan Model dilakukan untuk mengetahui apakah ROE dan DER secara bersamasama berpengaruh terhadap Return saham atau tidak (Ghozali, 2013). Menurut tabel 5, Sig. bernilai $0,245>0,05$. Berdasarkan hasil uji kecocokan model maka disimpulkan bahwa Profitabilitas (ROE) dan Leverage (DER) secara simultan tidak berpengaruh pada Return Saham.

Uji t

Tabel 6

Hasil Uji t

Coefficients $^{a}$

\begin{tabular}{|c|c|c|c|c|c|c|c|c|}
\hline & \multirow[b]{2}{*}{ Model } & \multicolumn{2}{|c|}{$\begin{array}{c}\text { Unstandardized } \\
\text { Coefficients }\end{array}$} & \multirow{2}{*}{$\begin{array}{c}\text { Standardized } \\
\text { Coefficients }\end{array}$} & & \multicolumn{3}{|c|}{$\begin{array}{l}\text { Collinearity } \\
\text { Statistics }\end{array}$} \\
\hline & & $B$ & Std. Error & & & Sig. & Tolerance & VIF \\
\hline \multirow[t]{3}{*}{1} & (Constant) & $-0,076$ & 0,132 & & $-0,572$ & 0,57 & & \\
\hline & $R O E(X 1)$ & 0,007 & 0,0 & 0,246 & 1,705 & 0,095 & 1,000 & 1,000 \\
\hline & $\operatorname{DER}(X 2)$ & 0,003 & 0,080 & 0,005 & 0,035 & 0,972 & 1,000 & 1,000 \\
\hline
\end{tabular}

Sumber : data yang diolah

Uji t digunakan untuk mengetahui apakah variabel bebas secara parsial memiliki pengaruh terhadap Return saham atau tidak (Ghozali, 2013). Menurut tabel 6, hasil uji t menunjukkan bahwa Sig. 
ROE bernilai 0,095 > 0,05 maka disimpulkan Profitabilitas (ROE) tidak berpengaruh pada Return saham dan Sig. DER 0,972>0,05 maka disimpulkan Leverage (DER) tidak berpengaruh pada Return saham.

\section{Pengaruh Profitabilitas Terhadap Return saham}

Menurut $\mathrm{H}_{1}$, profitabilitas berpengaruh terhadap Return saham. Hasil uji hipotesis memperlihatkan koefisien profitabilitas yang diproksikan dengan ROE yaitu 0,007 maka H1 ditolak (Sig. 0,095 > 0,05) memperlihatkan Profitabilitas tidak berpengaruh pada Return saham sehingga profitabilitas tidak menjadi ukuran bagi investor sebagai acuan dalam berinvestasi, melainkan ada faktor lain yang tidak dikaji pada pengkajian ini. Investor tidak semata-mata hanya memperhatikan profitabilitas sebagai acuan dalam investasi. Salah satu tujuan investor adalah untuk mendapatkan Return saham dan tidak ada investor yang akan melakukan investasi apabila tidak mendapatkan imbal balik sehingga ROE sangat diperhatikan oleh analis saham dan investor dimana ROE yang tinggi menunjukkan bahwa perusahaan lebih mampu menghasilkan laba secara optimal dan Return yang diterima juga akan semakin tinggi. Pada penelitian Aisah \& Mandala (2016), Aulidani et al. (2020), Fitri (2018), dan Kampongsina et al. (2020) menyatakan profitabilitas tidak berpengaruh pada Return saham. Namun, pada Fitriana et al. (2016), Kevin et al. (2020), dan Saputra \& Dharmadiaksa (2016) menyatakan profitabilitas memengaruhi Return saham.

\section{Pengaruh Leverage Terhadap Return Saham}

Menurut $\mathrm{H}_{2}$, Leverage berpengaruh terhadap Return saham. Hasil uji hipotesis memperlihatkan koefisien Leverage yang diproksikan dengan DER yaitu 0,003 maka $\mathrm{H}_{2}$ ditolak (Sig. 0,972 > 0,05) memperlihatkan Leverage tidak berpengaruh pada Return saham dan tidak menjadi ukuran bagi investor sebagai acuan dalam berinvestasi, melainkan ada faktor lain yang tidak dikaji pada pengkajian ini. Apabila kondisi Leverage perusahaan kurang menguntungkan, maka umumnya Return yang diberikan perusahaan akan menurun karena laba yang diperoleh lebih banyak digunakan untuk melunasi hutang. Penelitian ini sejalan pada penelitian Aisah \& Mandala (2016), Aulidani et al. (2020), Fitri (2018), Sinaga et al. (2020), dan Kampongsina et al. (2020) menyatakan Leverage tidak berpengaruh pada Return saham. Namun, pada Fitriana et al. (2016), Putra \& Dana (2016), dan Sari \& Priyadi (2016) menunjukkan Leverage dapat memengaruhi Return saham, semakin tinggi DER maka komposisi hutang akan tinggi sehingga upaya perusahaan membayar deviden sebagai Return saham akan rendah.

\section{KESIMPULAN}

Hasil uji normalitas menunjukkan bahwa model regresi dinyatakan terdistribusi normal. Hasil uji Multikolinieritas, autokorelasi, dan heterokedastisitas menunjukkan bahwa penelitian ini tidak terdapat multikolinieritas, autokorelasi dan heterokedastisitas. Hasil uji kecocokan model dan uji t menunjukkan bahwa ROE dan DER tidak berpengaruh terhadap Return saham. Berdasarkan penelitian yang telah dilakukan mengenai pengaruh Profitabilitas dan Leverage terhadap Return saham pada sektor pertambangan batu bara yang terdaftar di BEI tahun 2017-2019, dapat disimpulkan bahwa Profitabilitas yang diproksikan dengan $R O E$ tidak berpengaruh terhadap Return saham dan Leverage yang diproksikan dengan $D E R$ tidak berpengaruh terhadap Return saham sehingga perubahan yang terjadi pada ROE dan DER tidak akan mempengaruhi Return saham.

\section{SARAN}

\section{Saran Praktis}

Bagi para investor dan manajer investasi sebaiknya mengambil keputusan pembelian saham di pasar modal tidak hanya mempertimbangkan rasio profitabilitas dan Leverage dalam berinvestasi tetapi juga melihat aspek-aspek lain yang dapat mempengaruhi Return saham seperti rasio likuiditas, aktivitas dan investasi.

\section{Saran Teoritis}

- Meningkatkan jumlah data dan periode pengamatan agar hasil menjadi lebih akurat.

- Memakai sampel dan jenis perusahaan lain sebagai tambahan referensi agar tidak terbatas pada sektor pertambangan batu bara.

- Menambah jumlah variabel yang akan memengaruhi Return saham agar mendapatkan hasil penelitian yang lebih baik. 


\section{REFERENSI}

Aisah, A., \& Mandala, K. (2016). Pengaruh Return on Equity, Earning Per Share, Firm Size Dan Operating Cash Flow Terhadap Return Saham. E-Jurnal Manajemen Universitas Udayana, 5(11).

Almira, N. P. A. K., \& Wiagustini, N. L. P. (2020). Return on Asset, Return on Equity, Dan Earning Per Share Berpengaruh Terhadap Return Saham. E-Jurnal Manajemen Universitas Udayana, 9(3), 1069.

Aulidani, Z., Pranoto, S., \& Sulistyowati, E. (2020). Analisis Return Saham Melalui Rasio Keuangan Dengan Nilai Tukar Sebagai Variabel Moderasi (Studi pada Perusahaan Sektor Consumer Goods Industry di Bursa Efek Indonesia Tahun 2014-2018). Jurnal Manajemen Dan Bisnis, 5(1).

Bisara, C., \& Amanah, L. (2015). Pengaruh Kinerja Keuangan Terhadap Return Saham. Jurnal Ilmu \& Riset Akuntansi, 4(2), 1-14.

Fenty, F. (2017). Kesehatan Bank, Kebijakan Deviden, dan Nilai Perusahaan:Teori dan Kajian Empiris. Jakarta:Pustaka Horizon.

Fitri, R. (2018). Pengaruh Kebijakan Dividen, Leverage Perusahaan Dan Profitabilitas Terhadap Return Saham (Studi Pada Perusahaan Sub Sektor Makanan Dan Minuman Yang Terdaftar Di BEI). Jurnal Ilmiah Bisnis Dan Ekonomi Asia, 11(2), 32-37.

Fitriana, D., Oemar, A., \& Andini, R. (2016). Pengaruh Likuiditas, Solvabilitas,Profitabilitas, Aktivitas Dan Kebijakan Dividen Terhadap Return Saham Perusahaan Pertambangan Yang Terdaftar Pada Bei Periode 2007-2013. Journal Of Accounting, 2(2), 1-19.

Ghozali, I. (2011). Aplikasi Analisis Multivariate Dengan Program SPSS. Semarang:Badan Penerbit UNDIP.

Ghozali, I. (2013). Aplikasi Analisis Multivariate Dengan Program SPSS (7th ed.). Semarang:Badan Penerbit UNDIP.

Jogiyanto, H. (2013). Teori Portofolio dan Analisis Investasi. Yogyakarta:BPFE UGM.

Kampongsina, C. E., Murni, S., Untu, V. N., Sam, U., \& Manado, R. (2020). Pengaruh Current Ratio, Debt To Equity Dan Return On Equity Terhadap Return Saham Pada Perusahaan Farmasi Yang Terdaftar Di BEI (Periode 2015-2019). 8(4), 1029-1038.

Kasmir. (2015). Analisis Laporan Keuangan. Jakarta:PT Raja Grafindo Persada.

Kevin Pratama, Gideon S.B, Dwi Suhartini, N. (2020). Peran Kebijakan Dividen Dalam Memoderasi Profitabilitas dan Likuiditas Terhadap Nilai Perusahaan. Jurnal Manajemen Dan Bisnis, 5, 18-23.

Mahardika, I., \& Artini, L. (2017). Pengaruh Rasio Pasar Dan Rasio Profitabilitas Terhadap Return Saham Perusahaan Di Bursa Efek Indonesia. E-Jurnal Manajemen Universitas Udayana, 6(4).

Martha, L., Sogiroh, N. U., Magdalena, M., Susanti, F., \& Syafitri, Y. (2018). Profitabilitas Dan Kebijakan Dividen Terhadap Nilai Perusahaan. Jurnal Benefita, 3(2), 227.

Prihadi, T. (2016). Analisis Laporan Keuangan : Konsep dan Aplikasi. PT Gramedia Pustaka Utama.

Putra, I. M. G. D., \& Dana, I. M. (2016). Pengaruh Profitabilitas, Leverage, Likuiditas Dan Ukuran Perusahaan Terhadap Return Saham Perusahaan Farmasi Di BEI. E-Jurnal Manajemen Universitas Udayana, 5(11), 6825-6850.

Safitri, O., Sinarwati, \& Atmadja, A. T. (2015). Analisis Pengaruh Profitabilitas, Likuiditas,dan Leverage Terhadap Return Saham Pada Perusahaan Manufaktur Yang Terdaftar di BEI Tahun 2009-2013. Jurnal Akuntansi, 3(1), 1-12.

Saputra, I. G. A., \& Dharmadiaksa, I. B. (2016). Pengaruh Tingkat Suku Bunga, Nilai Tukar Rupiah, Leverage Dan Profitabilitas Pada Return Saham. E-Jurnal Akuntansi Universitas Udayana, 16(45), 1003-1033.

Sari, R. A. I., \& Priyadi, M. P. (2016). Pengaruh Leverage, Profitabilitas , Size , Dan Growth Opportunity Terhadap Nilai Perusahaan. Jurnal Ilmu Dan Riset Manajemen, 5(10), 2-17.

Sayidah, N. (2019). Pengaruh Ukuran Perusahaan, Profitabilitas, Solvabilitas Dan Opini Auditor Terhadap Audit Delay. Jurnal Analisa Akuntansi Dan Perpajakan, 2(2).

Sinaga, A. N., Eric, Rudy, \& Wiltan, V. (2020). Current Ratio, Debt to Equity Ratio, Return On Equity, Dividend Payout Ratio dan Size Terhadap Return Saham Perusahaan Trade, Service \& Investment Indonesia. Journal of Economic, Business, and Accounting, 3(2), 311-318.

Tumiur, R. (2019). Pengaruh Kinerja Keuangan Terhadap Return Saham Perusahaan Pertambangan. Jurnal Bisnis Dan Akuntansi, 21(2), 155-164. 